NBER WORKING PAPER SERIES

\title{
IMITATIVE OBESITY AND RELATIVE UTILITY
}

\author{
David G. Blanchflower \\ Andrew J. Oswald \\ Bert Van Landeghem \\ Working Paper 14337 \\ http://www.nber.org/papers/w14337
NATIONAL BUREAU OF ECONOMIC RESEARCH
1050 Massachusetts Avenue
Cambridge, MA 02138
September 2008

We are grateful to Alois Stutzer for many helpful ideas on the topic of obesity, and to Gordon D.A. Brown for discussions on the possible role of ordinal rank in BMI. For valuable suggestions, we thank also John Cawley, Nicholas Christakis, Andrew Clark, Armin Falk, Amanda Goodall, Carol Graham, Nick Powdthavee, Dan Wilson, and participants at the 2008 NBER Health Economics and Health Policy Workshops and the 2008 EEA Milan Meeting. The views expressed herein are those of the author(s) and do not necessarily reflect the views of the National Bureau of Economic Research.

NBER working papers are circulated for discussion and comment purposes. They have not been peerreviewed or been subject to the review by the NBER Board of Directors that accompanies official NBER publications.

(C) 2008 by David G. Blanchflower, Andrew J. Oswald, and Bert Van Landeghem. All rights reserved. Short sections of text, not to exceed two paragraphs, may be quoted without explicit permission provided that full credit, including (C) notice, is given to the source. 
Imitative Obesity and Relative Utility

David G. Blanchflower, Andrew J. Oswald, and Bert Van Landeghem

NBER Working Paper No. 14337

September 2008

JEL No. D01,I12,I31

\begin{abstract}
$\underline{\text { ABSTRACT }}$
If human beings care about their relative weight, a form of imitative obesity can emerge (in which people subconsciously keep up with the weight of the Joneses). Using Eurobarometer data on 29 countries, this paper provides cross-sectional evidence that overweight perceptions and dieting are influenced by a person's relative BMI, and longitudinal evidence from the German Socioeconomic Panel that well-being is influenced by relative BMI. Highly educated people see themselves as fatter -- at any given actual weight -- than those with low education. These results should be treated cautiously, and fixed-effects estimates are not always well-determined, but there are grounds to take seriously the possibility of socially contagious obesity.
\end{abstract}

David G. Blanchflower

Bruce V. Rauner Professor of Economics 309B Silsby Hall

Dartmouth College

Hanover, NH 03755-3514

and NBER

david.g.blanchflower@dartmouth.edu

Andrew J. Oswald

Department of Economics

University of Warwick

Coventry CV4 7AL

England

a.j.oswald@warwick.ac.uk
Bert Van Landeghem

LICOS Centre for Institutions and Economic Performance

Belgium

Bert.VanLandeghem@econ.kuleuven.be 


\section{Introduction}

The industrialized world is becoming steadily fatter. Because of the shortened longevity and the diseases -- such as diabetes -- that are associated with being overweight, this phenomenon is of concern to governments and the medical profession.

Why has obesity risen? The consumption of calories has gone up (Bleich et al, 2008), but that does not tell us why people are eating ${ }^{1}$ more. Some writers, such as Offer (2006), argue that rising weights have been produced by falling food prices. Yet it is not easy to see how this trigger can be large enough to match the data, and the puzzle remains of why, if fatness is a response to greater real purchasing power, we observe in western countries that rich people are typically thinner than poor people. ${ }^{2}$

Some commentators speak of an obesity 'epidemic'. Such language is evocative of the idea that fatness can spread from one person to another. In interesting work at the border between medicine and quantitative sociology, Christakis and Fowler (2007) have recently produced evidence consistent with just such an idea. ${ }^{3}$ They find that gains in weight appear to spread through a population -- with friends and relatives apparently influencing other friends and relatives, for example -- in a way reminiscent of a contagious disease. Burke and Heiland (2007), Etile (2007), and Oswald and Powdthavee (2007) present models in the same spirit. The first two papers assume that

\footnotetext{
1 Cutler et al (2003) and Brunello et al (2008) are valuable overviews of the intellectual and policy issues. De Agostini (2007) suggests that it is not calories consumed at home that are causing the rise in weights. Chou et al (2004) examines the role of restaurant-food prices, and Morris and Gravelle (2008) of the local supply of doctors. Gruber and Frakes (2006) are doubtful that the secular decline in smoking is what has raised obesity.

2 See sources such as Banks et al (2006), Bhattacharya and Bundorf (2005), Propper (2005), Finkelstein et al (2005), and Sanz-de-Galdeano (2005). Links between obesity and labour-market outcomes are studied in Sargent and Blanchflower (1994), Cawley (2004) and Morris (2006). However, Kenkel et al (2006) does not find strong links between high-school completion and later obesity.

3 A recent critique of Christakis and Fowler (2007) is that of Cohen-Cole and Fletcher (2008).
} 
people like to have a weight close to other people's weight. The third paper instead argues that people have a utility function defined on relative weight and rationally choose a weight after observing the weights of their peers. Felton and Graham (2005) suggest that changing norms lie at the heart of the obesity phenomenon. Etile (2007) argues similarly, and documents interesting French data on weight satisfaction. In a related spirit, Maximova et al (2008) have recently shown that young people's perceptions of weight and overweight depend upon the weight of their parents and friends, and Trogdon et al (2008) report data on the same issue; Ellaway et al (1997) suggest that different places may have different norms of body weight; and Chen and Meltzer (2008) argue that Chinese obesity is increasing because of changing norms and social contagion.

Despite this research, little is currently known about the possible mechanisms at work. The paper is an attempt to shed light on those.

\section{Relative comparisons and obesity}

A longstanding idea in social science is that -- perhaps for Darwinian reasons -utility may depend on a person's relative income. The work of Duesenberry (1949) and Frank (1985) has particularly moulded economists' thinking.

We consider an equivalent possibility. It is that a person's utility may depend on relative weight. Such an idea is somewhat in the spirit of Clark (2003) and Powdthavee (2007), who argue that, perhaps for reasons of reduced stigma, it is psychologically preferable to be unemployed in an area where there are many other jobless people. Creative work by Daly, Wilson and Johnson (2007) shows that even suicide decisions appear to be affected by comparisons. For a variety of reasons, it may be easier to be fat in a society that is fat. It is possible to construct a model where concern for relative 
weight leads to obesity spirals, and where this happens after only small drops in the price of food. In a world of comparisons, such as Luttmer (2005), people will often emulate each other in a kind of keeping-up-with-the-Joneses sense, and, as a theoretical idea, fatness can then in principle spread in a way that would have the appearance of a contagious effect. However, deviant slimness can emerge rationally among some in the population, and the sign of the second derivative 4 of the utility function (with respect to relative weight) turns out to be crucial.

Assume that relative slimness confers status. If there are gains from such status -perhaps better mates or faster job promotion -- then if I have diminishing returns I will invest in status less the more status I have. However, as pointed out in Oswald and Powdthavee (2007), if I have a convex utility function over the status from being slim, I will act in the opposite way. Two phenomena can then appear simultaneously: a spiral in obesity while some people choose to be thinner.

Let $\mathrm{b}$ be body mass, and $\mathrm{f}(\mathrm{b})$ be its density in the population. Imagine that social status comes from being slimmer than the herd. Assume it depends smoothly on the gap between average weight and one's own. Define mean body mass, m, as:

$$
m=\int_{0}^{\bar{b}} b f(b) d b .
$$

Assume utility from body mass b comes in two forms: there is both a direct (whether gain or loss) effect from the consequences of eating and an indirect 'status' effect. Assume there is also a marginal cost, c, to being fat, which might be primarily financial but

\footnotetext{
${ }^{4}$ For more general mathematics in imitative settings, see Clark and Oswald (1998). Hopkins and Kornienko $(2004,2006)$ provide formal models of status games and comparisons.
} 
perhaps also in terms of health and mobility. Let the individual's maximand be given by utility function

$W=u(b)+\mu(m-b)-c b$,

so that, ignoring corners, the first-order condition for optimal weight is

$\frac{\partial W}{\partial b}=u^{\prime}(b)-\mu^{\prime}(m-b)-c=0$.

In this case, if society becomes heavier, in the sense that the mean of the weight distribution goes up, a rational individual will imitate the rest of the population if he or she has a concave utility function. This is because the sign of the comparative static derivative $\mathrm{db} / \mathrm{dm}$ is given by the $\operatorname{sign}^{5}$ of:

$\frac{\partial^{2} W}{\partial b \partial m}=-\mu^{\prime \prime}(m-b)$.

This expression is positive if $\mu($.$) , the status part of the utility function, is strictly$ concave. Hence the existence of imitative keeping-up-with-the-Jones' in body weight will occur among those with a utility function that exhibits diminishing marginal utility in relative slimness 6 .

3. Data

We begin with the patterns in modern cross-section Eurobarometer data on 29 nations. Then we turn to longitudinal data in a number of sweeps of the German

5 This is because, at the interior maximum of a function $J(x, a)$ with respect to $x$, both $J_{x x}(x, a) d x+J_{x a}(x, a) d a=0$ holds locally and $J$ is necessarily concave in the argument $x$.

6 Interestingly, Stutzer $(2006,2007)$ demonstrates that obesity is associated with reduced well-being most especially among a sub-sample of people who report that they have limited self-control. 
Socioeconomic Panel (GSOEP). All tables ${ }^{7}$ use self-reported data to construct BMI figures, and as such can be only a first step.

Our central conclusion is that, while much remains to be understood, there is empirical support for the idea that comparisons and relative-weight play a role. It may be that people's preference functions contain as an argument their relative BMI. If so, this is consistent, under concavity conditions explained above, with the idea that there might be emulation of others' weights.

We calculate self-reported kilos/metres-squared BMI (body mass index) in each of the 29 countries in the Eurobarometer sample. The data are set out in the longer working-paper version of this paper. We agree with Burkhauser and Cawley (2008) that this measure of fatness has limitations, but for simplicity in this paper BMI is taken as the standard. The data are for the year 2005 , and are based on information on approximately 1000 randomly selected people in each nation.

Europe's nations report numbers that imply a mean BMI of approximately 25.4 for men and 24.5 for women. The highest body mass index values for males are in Malta at 26.9 and Slovenia and Greece at 26.4; the lowest BMI values are found in Turkey at 24.8 and Netherlands and Italy at 25.0. For women, Italy and France have the lowest BMIs at 23.5 and 23.8; Malta comes in highest at 26.2. There is likely, of course, to be measurement error -- possibly of a considerable size -- in these numbers.

\footnotetext{
7 Standard controls are included in these equations, although are not discussed in detail here; Oswald (1997) and Frey and Stutzer (2002) are reviews, and the literature includes Clark and Oswald (1996), Blanchflower (2008), Blanchflower and Oswald (2004, 2008a,b), Di Tella et al (2001), Easterlin (1974, 2003), Van Praag and Ferrer-I-Carbonell (2004), and Winkelmann and Winkelmann (1998). Jorm et al (2003) and Simon et al (2006) find a correlation between obesity and depression, and debate whether it is a causal connection. Doll et al (2000) uncover stronger links to physical, rather than emotional, health.
} 
Individuals in the Eurobarometer surveys are also asked "Would you say that your current weight is: Too low; About right; Too high?". In the entire sample, $31 \%$ of male Europeans, and $43 \%$ of female Europeans, say their own weight is too high. To explore the cross-section pattern across different kinds of people, we use these data to estimate in Table 1 a feeling-overweight regression equation. Among other findings, this is concave in BMI, with a notional turning point at approximately a BMI of 50. As shown in the first column of Table 1, feelings of overweight are also increasing in relative BMI (where the comparison group is the person's age-group for each gender in each nation). There is also a strong gender difference: females are much more prone, for any given BMI value, to feel overweight. There are signs -- not reported -- of a decreasing effect in age, particularly for women, and a marked correlation with Age Left School. As previously found in the work of Oswald and Powdthavee (2007) on British data, at any given level of BMI the most highly educated Europeans are more likely to view themselves as overweight. For example, the 'Age Left School over 20 ' coefficient is 0.5303 , with a tstatistic above 10 , in column 1 of Table 1 . The category is a proxy for being collegeeducated. The finding that greater levels of education are associated with a greater perception of high body weight is true among males and females; it operates monotonically in each of columns 2 and 3 in Table 1. It itself appears redolent of comparisons.

In Table 1, the coefficient on relative BMI seems of special interest. Here relative BMI is measured as an individual's BMI divided by the average BMI from their country*age band*gender cell. Age bands are defined in twelve five-year age groupings from $<20,20-24$, and so on in five year bands up to 69 , and then 70 and over. The 
coefficient on the relative BMI variable is approximately -1.7 for males, with a t-statistic of 1.78 , so the null of zero is not quite rejected at conventional levels, and the sign is inconsistent with the idea that people might worry about being fatter than others. For females, however, the coefficient is approximately 2.6 with a t-statistic of 4.51 . Hence there is evidence -- as a matter of correlation -- that, regardless of absolute BMI, those reporting fatness relative to their peers are more concerned about their own weight. Comparisons apparently matter: the absolute level of BMI itself is not a sufficient statistic.

Equivalent patterns show up in Table 2. It gives, for 1996, regressions using answers to: Here are some statements. For each of these, please tell me if you agree strongly, agree slightly, disagree slightly or disagree strongly?

- I am very satisfied with my body weight. Agree strongly=1 ... disagree strongly $=5$

- Over the last 12 months, have you been on a diet, or not?

and the data reveal particularly large numbers of women saying they have recently dieted.

The first two columns of Table 2 provide ordered logit equations in which the dependent variable is a measure of dissatisfaction with weight. For females, relative BMI is influential. The third and fourth columns of Table 2 are dprobit equations in which the dependent variable is 'having dieted in the last 12-months'. Greece, Luxembourg and the UK have the largest country dummies (not reported). Especially among Europe's females, a high value of relative BMI is a predictor of those who say they have been on a diet in the previous year: the coefficient is 0.6001 with a t-statistic of 4.07 . For women, there is little or no age-gradient in who diets, whereas for men it is mostly older males 
who diet. Once again, education enters strongly. Highly educated people are more likely, ceteris paribus, to be dissatisfied with their weight and to say they have been dieting.

How are mental well-being and BMI connected? For Europe, this is hard to establish in modern data, because the Eurobarometer surveys of 1996 and 2005 do not provide life-satisfaction or mental health scores (although Blanchflower (2008) estimates happiness and life satisfaction equations for other Eurobarometer data sets) ${ }^{8}$.

We turn to evidence from the German Socioeconomic Panel. There are three sweeps of the panel in which people are asked for their height and weight. Life satisfaction data (on a ten-point scale) are regularly collected. This makes it possible to estimate fixed-effects models of well-being in which BMI measures are included as regressors. In Table 3, the first three columns are pooled OLS equations in which life satisfaction is the dependent variable. For simplicity, life satisfaction is treated cardinally; ordered estimators give similar results. Standard controls, including education and income, are included in the cross-section equations. In linear specifications -- not reported -- a negative association between life satisfaction and BMI is found, and is especially clear for German women. Most of the evidence is consistent with that from cross-sectional work for the United States in Felton and Graham (2005), Switzerland in Stutzer (2006), Britain in Oswald and Powdthavee (2007), and the Netherlands in Cornelisse-Vermaat et al (2006), and also with some of the longitudinal associations in Roberts et al $(2000,2002)$ and Graham (2008). Hence, even controlling for many personal characteristics, fatter people here are less satisfied with their lives. The standard

\footnotetext{
8 Goldberg et al (1997) and Gardner and Oswald (2007) discuss the construction of GHQ scores.
} 
deviation of BMI is approximately 5 for women. Thus a one-standard-deviation move up in body mass index is associated, in the cross-section, with approximately 0.1 fewer lifesatisfaction points among German women. However, Table 3 includes non-linear BMI terms, which are strongly favoured by the data.

There is evidence in Table 3 of a role for relative BMI. The variable Relative BMI is defined as the person's BMI divided by a comparison peers' BMI level (defined as a cell mean given by year and gender and federal state and education). Table 3's lifesatisfaction equations find that, in fixed-effects estimation, relative BMI enters positively even after allowing for a quadratic form in BMI. For the male sub-sample, it is possible at $5 \%$ significance to reject the null of zero on the variable for Relative BMI. Therefore, after differencing out person-effects, life satisfaction rises among those men who live in an area populated by individuals who are growing fatter 9 .

This provides some evidence that there is a utility gain from relative thinness. Nevertheless, deep issues of causality remain unaddressed in our analysis. More work will be required before the paper's empirical findings can be viewed as more than suggestive.

\section{Conclusions}

This paper documents international patterns in well-being, dieting, and people's perceptions of being overweight. It draws upon samples from the 1996 and 2005 Eurobarometer Surveys and from three recent sweeps of the German Socioeconomic

\footnotetext{
9 This is akin to the relative-income findings of Blanchflower and Oswald (2004) and Luttmer (2005). Another possibility is that the ordinal rank of BMI may matter -in the spirit of the wage results in Brown et al (2008). Our results are also reminiscent of the social-interactions literature for other areas; see for example Clark and Loheac (2007).
} 
Panel. Although much remains to be understood, comparisons and relative-weight concerns seem to matter.

It may be that people's utility functions contain as an argument their relative BMI. If so this is consistent -- under concavity conditions that we discuss -- with the idea that there can be a Keeping up with the Joneses effect that manifests itself as a form of imitative obesity or 'contagion'10. Our findings are an example of the kinds of social interconnections discussed in Smith and Christakis (2008).

There are specific results. We find that more than one third of Europe's population view themselves as overweight. For a given level of BMI, highly educated people are the most likely to see themselves as fat. This suggests that people have different comparison groups: the highly educated hold themselves to a thinner standard. For European women, weight dissatisfaction and overweight perceptions depend upon not just their own absolute BMI but also upon BMI relative to their peers (where we use a measure of BMI divided by the average BMI in their age*gender*country group). The same, we find, is true of dieting decisions. In cross-section German GOESP well-being equations, there is often a negative effect from own-BMI, and there are signs of nonlinearities in the relationship. In fixed-effects equations, there is evidence that wellbeing is higher among those who are relatively -- not merely absolutely -- thin.

\footnotetext{
10 Despite the unattractive sound to this word, we do not mean it in a pejorative way. Another term would be 'spillovers'.
} 


\section{$\underline{\text { References }}$}

Banks, James, Michael Marmot, Zoe Oldfield, and James P. Smith (2006). "The SES Health Gradient on Both Sides of the Atlantic." National Bureau of Economic Research Paper No. 12674.

Bhattacharya, Jay, and M. Kate Bundorf (2005). "The Incidence of the Healthcare Costs of Obesity.” National Bureau of Economic Research Paper No. 11303.

Blanchflower, David G. (2008). "International Evidence on Well-Being.” IZA Paper No. 3354.

Blanchflower, David G. and Andrew J. Oswald (2004). "Well-being Over Time in Britain and the USA." Journal of Public Economics, 88, 1359-1386.

Blanchflower, David G. and Andrew J. Oswald (2008a). "Hypertension and Happiness Across Nations." Journal of Health Economics, 27, 218-233.

Blanchflower, David G. and Andrew J. Oswald (2008b). "Is Well-Being U-Shaped Over the Life Cycle?" Social Science \& Medicine, 66, 1733-1749.

Blanchflower, David G., Andrew J. Oswald, and Bert Van Landeghem (2008). “Imitative Obesity and Relative Utility." Working paper presented at the NBER Summer Workshop and the European Economic Association Meeting (Milan).

Bleich, Sara, David Cutler, Christopher Murray, and Alyce Adams (2008). "Why is the Developed World Obese?” Annual Review of Public Health, 29, 273-295.

Brown, Gordon D.A., Jonathan Gardner, Andrew J. Oswald, and Jing Qian (2008). “Does Wage Rank Affect Employees’ Well-being?” Industrial Relations, 47, 355-389.

Brunello, Giorgio., Pierre-Carl Michaud, and Anna Sanz-de-Galdeano (2008). "The Rise in Obesity Across the Atlantic: An Economic Perspective.” IZA Paper, June 2008. 
Burke, Mary A. and Frank Heiland. (2007). "Social Dynamics of Obesity." Economic Inquiry, 45, 571-591.

Burkhauser, Richard V. and John Cawley (2008). "Beyond BMI: The Value of More Accurate Measures of Fatness and Obesity in Social Science Research." Journal of Health Economics, 27, 519-529.

Cawley, John (2004). “The Impact of Obesity on Wages." Journal of Human Resources, $39,451-474$.

Chen, Zhuo and David Meltzer (2008). "Beefing Up with the Chans: Evidence for the Effects of Relative Income and Income Inequality on Health from the China Health and Nutrition Survey.” Social Science \& Medicine, 66, 2206-2217.

Chou, Shin Yi, Michael Grossman, and Henry Saffer (2004). "An Economic Analysis of Adult Obesity: Results from the Behavioral Risk Factor Surveillance System.” Journal of Health Economics, 23, 565-587.

Christakis, Nicholas A. and James H. Fowler (2007). "The Spread of Obesity in a Large Social Network over 32 Years.” New England Journal of Medicine, 357, 370-379.

Clark, Andrew E. (2003). "Unemployment as a Social Norm: Psychological Evidence from Panel Data." Journal of Labor Economics, 21, 323-351.

Clark, Andrew E. and Youenn Loheac (2007). "It Wasn't Me, It Was Them! Social Influence in Risky Behaviour by Adolescents." Journal of Health Economics, 26, 763-784.

Clark, Andrew E. and Andrew J. Oswald (1996). "Satisfaction and Comparison Income." Journal of Public Economics, 61, 359-381. 
Clark, Andrew E. and Andrew J. Oswald (1998). "Comparison-Concave Utility and Following Behaviour in Social and Economic Settings." Journal of Public Economics, 70, 133-150.

Cohen-Cole, Ethan and Jason M. Fletcher (2008). "Is Obesity Contagious? Social Networks VS. Environmental Factors in the Obesity Epidemic." Journal of Health Economics, 27, 1382-1387.

Cornelisse-Vermaat, Judith R., Gerrit Antonides, Johan A.C. Van Ophem, and Henrietta Van Den Brink (2006). "Body Mass Index, Perceived Health, and Happiness: Their Determinants and Structural Relationships." Social Indicators Research, 79, 143158.

Cutler, David M., Edward L. Glaeser, and Jesse M. Shapiro (2003). "Why Have Americans Become More Obese?” Journal of Economic Perspectives, 17, 93-118.

Daly, Mary C., Daniel J. Wilson, and Norman J. Johnson (2007). "Relative Status and Well-Being: Evidence from US Suicide Deaths." Working Paper, Federal Reserve Bank of San Francisco.

De Agostini, Paola (2007). "Diet Composition, Socioeconomic Status and Food Outlets Development in Britain.” ISER Working Paper, University of Essex.

Di Tella, Rafael, Robert J. MacCulloch, and Andrew J. Oswald (2001). "Preferences Over Inflation and Unemployment: Evidence from Surveys of Happiness." American Economic Review, 91, 335-341.

Doll, Helen A., Sophie E. K Petersen, and Sarah L. Stewart-Brown (2000). "Obesity and Physical and Emotional Well-Being: Associations Between BMI, Chronic Illness, 
and the Physical and Mental Components of the SF-36 Questionnaire." Obesity Research, 8, 160-170.

Duesenberry, James S. (1949). Income, Saving and the Theory of Consumer Behavior. Harvard University Press: Cambridge, MA.

Easterlin, Richard A. (1974). "Does Economic Growth Improve the Human Lot? Some Empirical Evidence." In P.A. David and M. W. Reder (Eds.), Nations and Households in Economic Growth: Essays in Honor of Moses Abramowitz. Academic Press: New York.

Easterlin, Richard A. (2003). "Explaining Happiness." Proceedings of the National Academy of Sciences, 100, 11176-11183.

Ellaway, Anne, Anne Anderson, and Sally Macintyre (1997). "Does Area of Residence Affect Body Size and Shape?” International Journal of Obesity, 21, 304-308.

Etile, Fabrice (2007). "Social Norms, Ideal Body Weight and Food Attitudes." Health Economics, 16, 945-966.

Felton, Andrew and Carol Graham (2005). "Variance in Obesity Across Cohorts and Countries: A Norms-Based Explanation Using Happiness Surveys." Working Paper, Brookings Institution, Washington.

Finkelstein, Eric A., Christopher J. Ruhm, and Katherine M. Kosa (2005). "Economic Causes and Consequences of Obesity." Annual Review of Public Health, 26, 239257.

Frank, Robert H. (1985). Choosing the Right Pond: Human Behaviour and the Quest for Status. Oxford University Press: London. 
Frey, Bruno S. and Alois Stutzer (2002). Happiness and Economics: How the Economy and Institutions Affect Human Well-being. Princeton University Press: Princeton.

Gardner, Jonathan and Andrew J. Oswald (2007). "Money and Mental Wellbeing: A Longitudinal Study of Medium-Sized Lottery Wins." Journal of Health Economics, $26,49-60$.

Goldberg, David P., Richard Gater, Norman Sartorius, Bedirhan T. Ustun, Marina Piccinelli, Oye Gureje, and Cindy Rutter (1997). "The Validity of Two Versions of the GHQ in the WHO Study of Mental Illness in General Health Care." Psychological Medicine, 27, 191-197.

Graham, Carol (2008). "Happiness and Health: Lessons - and Questions - for Public Policy." Health Affairs, 27, 72-87.

Gruber, Jonathan and Michael Frakes (2006). "Does Falling Smoking Lead to Rising Obesity?" Journal of Health Economics, 25, 183-197.

Hopkins, Ed. and Tatiana Kornienko (2004). "Running to Keep in the Same Place: Consumer Choice as a Game of Status." American Economic Review, 94, 10851107.

Hopkins, Ed. and Tatiana Kornienko (2006). "Methods of Social Comparison in Games of Status.” Working Paper, University of Edinburgh.

Jorm, Anthony F., Ailsa E. Korten, Helen Christensen, Patricia A. Jacomb, Bryan Rodgers, and Rosemary A. Parslow (2003). "Association of Obesity with Anxiety, Depression and Emotional Well-Being: A Community Survey." Australian and New Zealand Journal of Public Health, 27, 434-440. 
Kenkel, Donald, Dean Lillard, and Alan Mathios (2006). "The Roles of High School Completion and GED Receipt in Smoking and Obesity." Journal of Labor Economics, 24, 635-660.

Luttmer, Erzo F.P. (2005). "Neighbors as Negatives: Relative Earnings and Well-Being." Quarterly Journal of Economics, 120, 963-1002.

Maximova, Katerina, John J. McGrath, Tracie Barnett, Jennifer O'Loughlin, Gilles Paradis, Martin Lambert (2008). "Do You See What I see? Weight Status Misperception and Exposure to Obesity Among Children and Adolescents." International Journal of Obesity, 32, 1008-1015.

Morris, Stephen (2006). "Body Mass Index and Occupational Attainment." Journal of Health Economics, 25, 347-364.

Morris, Stephen and Hugh Gravelle (2008). "GP Supply and Obesity." Journal of Health Economics, forthcoming.

Offer, Avner (2006). The Challenge of Affluence: Self-Control and Well-being in the United States and Britain Since 1950, Oxford University Press: Oxford.

Oswald, Andrew J. (1997). "Happiness and Economic Performance.” Economic Journal, $107,1815-1831$.

Oswald, Andrew J. and Nattavudh Powdthavee (2007). "Obesity, Unhappiness, and the Challenge of Affluence: Theory and Evidence.” Economic Journal, 117, F441- 454.

Powdthavee, Nattavudh (2007). "Are There Geographical Variations in the Psychological Costs of Unemployment in South Africa?" Social Indicators Research, 80, 629-652. Propper, Carol (2005). "Why Economics is Good for Your Health - 2004 RES Public Lecture.” CMPO paper No. 05/116, Bristol University. 
Roberts, Robert E., George A. Kaplan, Sarah J. Shema, and William J. Strawbridge (2000). "Are the Obese at Greater Risk of Depression?" American Journal of Epidemiology, 152, 163-170.

Roberts, Robert E., William J. Strawbridge, Stéphane Deleger, and George A. Kaplan (2002). “Are The Fat More Jolly?” Annals of Behavioral Medicine, 24, 169-180.

Sanz-de-Galdeano, Anna. (2005). "The Obesity Epidemic in Europe.” IZA Paper No. 1814.

Sargent, James D. and David G. Blanchflower (1994). "Obesity and Stature in Adolescence and Earnings in Young Adulthood - Analysis of a British Birth Cohort", Archives of Pediatrics \& Adolescent Medicine, 148, 681-687.

Simon, Gregory E., Michael Von Korff, Kathleen Saunders, Diana L. Miglioretti, Paul K. Crane, Gerald van Belle, and Ronald C. Kessler (2006). "Association Between Obesity and Psychiatric Disorders in the US Adult Population." Archives of General Psychiatry, 63, 824-830.

Smith, Kirsten P. and Nicholas A. Christakis (2008). "Social Networks and Health", Annual Review of Sociology, 34, 405-429.

Stutzer, Alois (2006). "When Temptation Overwhelms Will-Power: Obesity and Happiness.” Working Paper, University of Basel.

Stutzer, Alois (2007). "Limited Self-Control, Obesity, and the Loss of Happiness." IZA Working Paper No. 2925.

Trogdon, Justin G., James Nonnemaker, and Joanne Pais. (2008). "Peer Effects in Adolescent Overweight." Journal of Health Economics, 27, 1388-1399. 
Van Praag, Bernard and Ada Ferrer-I-Carbonell. (2004). Happiness Quantified: A Satisfaction Calculus Approach, Oxford University Press: Oxford.

Winkelmann, Liliana, and Rainer Winkelmann (1998). "Why Are the Unemployed So Unhappy? Evidence From Panel Data.” Economica, 65, 1-15. 
Table 1: Feeling-Overweight Equations: Eurobarometer Data 2005

\begin{tabular}{lccc} 
& \multicolumn{1}{c}{ All } & Male & \multicolumn{1}{c}{ Female } \\
BMI & $.7734(13.33)$ & $1.0494(17.58)$ & $.9869(4.76)$ \\
BMI $^{2}$ & $-.0074(6.09)$ & $-.0080(7.53)$ & $-.0111(2.71)$ \\
Relative BMI & $3.7325(6.97)$ & $-1.7354(1.78)$ & $2.6194(4.51)$ \\
Male & $-1.2309(26.05)$ & & \\
Muslim & $-.4283(2.96)$ & $-.2272(1.06)$ & $-.6755(2.96)$ \\
Age left school 16-19 & $.3141(6.96)$ & $.2426(3.64)$ & $.3418(5.94)$ \\
Age left school $\geq 20$ & $.5303(10.19)$ & $.5065(6.26)$ & $.4997(7.47)$ \\
Still studying & $.4693(5.43)$ & $.3258(2.47)$ & $.5823(5.01)$ \\
No fulltime education & $-.5000(1.63)$ & $-.6316(2.07)$ & $-.3712(0.86)$ \\
cut1 & 13.1645 & 14.80430 .99 & 14.6552 \\
cut2 & 18.2455 & 20.1276 & 19.7208 \\
N & 27,092 & 12,199 & 14,893 \\
Pseudo $\mathrm{R}^{2}$ & .3334 & .3304 & .3388
\end{tabular}

These are ordered logit equations. t-statistics are in parentheses. Country dummies and age-band dummies are included; the omitted category is Age left school $<16$. Standard errors are clustered by country and 12 age-bands. Source: Eurobarometer \#64.3: Foreign Languages, Biotechnology, Organized Crime, and Health Items, November-December 2005. ICPSR - 4590

The question is 'Would you say that your current weight is...? $1=$ Too low; $2=$ About right; $3=$ Too high. Relative BMI is the individual's BMI divided by the average BMI in the age cell done separately by gender* country. Age bands are defined in twelve five-year age groupings from $<20 ; 20-24$; and so on in five-year bands up to 69 , and then 70 and over. 
Table 2: Equations for Weight Dissatisfaction and Have Dieted: Eurobarometer Data 1996

\begin{tabular}{|c|c|c|c|c|}
\hline & $\begin{array}{l}\text { Male dissfn. } \\
\text { Ologit }\end{array}$ & $\begin{array}{c}\text { Female dissfn } \\
\text { Ologit }\end{array}$ & $\begin{array}{c}\text { Dieted male } \\
\text { Dprobit }\end{array}$ & $\begin{array}{c}\text { Dieted female } \\
\text { Dprobit }\end{array}$ \\
\hline BMI & $.2387(1.61)$ & $.6065(7.71)$ & $.0176(1.72)$ & $.0239(2.75)$ \\
\hline $\mathrm{BMI}^{2}$ & $.0005(0.23)$ & $-.0072(5.32)$ & $-.0001(1.51)$ & $-.0004(4.48)$ \\
\hline Relative BMI & $-.7220(0.65)$ & $1.2250(2.03)$ & $.1595(1.08)$ & $.6001(4.07)$ \\
\hline Age left school 16-19 & $.1270(2.29)$ & $.1104(1.69)$ & $.0042(0.39)$ & $.0342(2.43)$ \\
\hline Age left school $\geq 20$ & $.4020(5.88)$ & $.2729(3.56)$ & $.0567(4.56)$ & $.0530(3.01)$ \\
\hline Still studying & $.4169(3.35)$ & $.1444(1.41)$ & $.0351(1.91)$ & $.0126(0.50)$ \\
\hline cut1 & 4.9084 & 9.4951 & & \\
\hline cut2 & 6.5522 & 11.1487 & & \\
\hline cut3 & 6.9526 & 11.5136 & & \\
\hline cut4 & 8.8019 & 13.1798 & & \\
\hline $\mathrm{N}$ & 7,245 & 7,035 & 7,251 & 7,045 \\
\hline Pseudo $\mathrm{R}^{2}$ & .0749 & .1068 & .0628 & .0748 \\
\hline
\end{tabular}

Country dummies and age-band are included; the omitted category is Age left school $<16$. t-statistics are in parentheses. Standard errors are clustered by country and age cell. Relative BMI is BMI/average BMI by gender by country for 12 age groups. Source: Eurobarometer \#44.3: Health Care Issues and Public Security, February-April 1996; ICPSR - 6752.

The questions are

Q1. Here are some statements. For each of these, please tell me if you agree strongly, agree slightly, disagree slightly or disagree strongly? I am very satisfied with my body weight. Agree strongly $=1$... disagree strongly $=5$.

Q2. Over the last 12 months, have you been on a diet, or not? 
Table 3. Life Satisfaction Equations: German Socioeconomic Panel Data for the Years 2002, 2004 and 2006

\begin{tabular}{lllllll} 
& \multicolumn{3}{l}{ Pooled OLS equations } & \multicolumn{3}{l}{ Fixed effects equations } \\
& All & Male & Female & All & Male & Female \\
BMI & 0.0337 & 0.0436 & 0.0550 & 0.1018 & 0.1364 & 0.0740 \\
& $(2.49)$ & $(1.36)$ & $(1.55)$ & $(4.39)$ & $(3.97)$ & $(2.33)$ \\
BMI squared & -0.0011 & -0.0013 & -0.0012 & -0.0008 & -0.0008 & -0.0007 \\
& $(5.52)$ & $(4.43)$ & $(4.18)$ & $(3.00)$ & $(2.24)$ & $(2.13)$ \\
Relative & & & & & & \\
BMI & 0.4359 & 0.7038 & -0.1767 & -0.7753 & -1.3695 & -0.2228 \\
& $(2.19)$ & $(0.94)$ & $(0.23)$ & $(1.78)$ & $(2.14)$ & $(0.37)$ \\
Constant & 4.9392 & 4.6110 & 5.4597 & 4.9848 & 8.3771 & 8.3361 \\
& $(26.88)$ & $(15.63)$ & $(21.82)$ & $(11.92)$ & $(5.71)$ & $(5.47)$ \\
Observations & 56,986 & 27,416 & 29,570 & 59,846 & 28,800 & 31,046 \\
R-squared & 0.12 & 0.14 & 0.11 & 0.03 & 0.04 & 0.03 \\
Number of individuals & & & 25,562 & 12,341 & 13,221
\end{tabular}

Robust t-statistics are in parentheses. Relative BMI is defined as the person's BMI/(others' BMI averaged over year and gender and federal state and education). Pooled OLS standard errors are clustered at the year and gender and federal state and education cell. Life satisfaction is measured on a scale from 0 to 10, with a mean and standard error of 6.9 and 1.8 respectively. $\mathrm{BMI}=$ (weight in kilos)/(height in meters squared) and has a mean and standard error of 25.5 and 4.5 respectively. Other covariates in the equations include age-band and time dummies, federal state dummies, the log of real household income, and an unemployment dummy. The pooled OLS regressions also include education dummies. 